Article

\title{
The Endless Metamorphoses of Sacrifice and Its Clashing Narratives
}

\author{
Josetxo Beriain (1) \\ I-Communitas, Institute for Advanced Social Research, Public University of Navarre, 31006 Pamplona, Spain; \\ josetxo@unavarra.es
}

Received: 19 November 2020; Accepted: 16 December 2020; Published: 19 December 2020

\begin{abstract}
This paper sets out (1) to provide an affirmative genealogy that shed light on the different forms taken by sacrifice, the origins of its various conceptual layers and the various social practices from which they come; (2) to analyze the initial conceptual layer proposed by Marcel Mauss and Henri Hubert and followed by Marcel Hénaff based on farming societies; (3) to analyze the rise of the anti-sacrificial narrative and its main landmarks, the problems of victims and the responses given by René Girard and Talcott Parsons; and finally (4) to analyze the dynamic tension between the tragic-apocalyptic narrative and the defensive-progressive narrative in modern times, and the main landmarks of each one.
\end{abstract}

Keywords: sacrifice; gift; victim; post-heroic; sacralization of the person

\section{Introduction: Distinction between Offerings and Sacrifice}

There are several erroneous prior assumptions that must be avoided when addressing the meaning and different expressions of sacrifice. The first is the idea that sacrifice fits into a purely taxonomic and classificatory approach obsessed with classifying it into different types without first defining it. Certain late 19th century British anthropologists (Tyler, Frazer) strove to do this. The second idea is the reducing of sacrifice to a mere expression of primitive barbarism as opposed to civilization. The third is that this sacrificial expression disappears within the format of a markedly teleological socio-anthropological conjecture, i.e., that the more modern and civilized a society is, the less the culture of sacrifice is present in it. Here I demonstrate that these assumptions are empirically false.

There is a large body of documentation on the history of religions, anthropology and sociology that includes tales of offerings and sacrifices made all over the world by groups of hunter-gatherers and, especially, in pastoral societies, i.e., among farmers. The first clue to profiling the concept of sacrifice can be found in certain Indo-European languages, as indicated by Emile Benveniste (1969, pp. 223-26, 187-88) and Joseph Henninger (1995, p. 544 et seq.). In Vedic Sanskrit there are other roots that also refer to the idea of sacrifice: Hav- juhoti "to sacrifice", hotar "sacrificial priest", hotra "sacrifice", Agni-hotra "sacrifice to the god Agni". Our term "sacrifice" comes from the Latin sacrificium (sacer, "holy"; facere, "to do"); it can also be understood as the act of sanctifying or consecrating an object. "Offering" is used as a synonym (or as a more inclusive category of which sacrifice is a subdivision) and means the presentation of a gift. "Offering" has its roots in the verb offerre, "to offer, present"; the verb yields the noun oblatio. The German word Opfer ("victim") also comes from offerre, but some experts also point to an etymological relationship with operari ("to act" or "to carry out"), thus evoking the idea of sacred action.

But although "offering" and "sacrifice" are related etymologically, in the ambit of ritual actions they are not the same thing. Jan van Baal introduces a major guiding distinction under which "I call an offering every act of presenting something to a supernatural being, a sacrifice an offering accompanied by the ritual killing of the object of the offering" (van Baal 1976, p. 161). A precedent for this can be 
found in a definition in William Robertson-Smith's contribution to the 1886 edition of the Encyclopaedia Britannica, where he distinguishes clearly between two types of sacrificial offering: "Hostia honoraria refers to the case in which the deity accepts a gift, while hostia piacularis refers to that in which the deity demands a life (the death of a living being, animal or human)" (Robertson-Smith 1886, p. 132).

\section{Social Origins of Sacrifice}

This distinction is crucial not just in determining the social origins of sacrifice but also in delimiting the concept itself (Beriain 2017). It was Marcel Mauss who first observed, back in 1924, that over 10,000 years ago, before the rise of agriculture and livestock farming in the Neolithic, there was already a kind of ceremonial exchange of gifts (offerings-presents-gifts) (Mauss [1924] 1971, pp. 155-269) between a sacralized nature and human beings (groups of hunter-gatherers), whose way of life had existed for two and a half million years. The invention of agriculture (Leakey 1982,1994) gave rise to a new type of exchange between gods and human beings (represented by groups of agricultural and livestock farmers): sacrifice. More recently, Marcel Hénaff ([2002] 2010, p. 164 et seq.), basing his arguments on, among other things, field work by Roberte Hamayon (1990, p. 375) involving Siberian hunting societies, states that between humans and animals there was an egalitarian relationship based on an alliance and the exchange of gifts. Kinship structures, as the core principle of social organization in any segmented society, extend to all living beings and creatures, rivers and mountains. All the ambits that make up reality are related. There is no ontological superiority through which any one of these elements stands out from the rest. An animal is a part of the nature that we take-hunt-receive, but for that we must offer-give back something in return. Life is a gift that we receive and do not produce ourselves, but for which we must offer-give back something somehow. Life itself is a gift. The sacredness of life manifests itself in its circulation through all areas of the real. Among hunter-gatherers, nature was not seen as something hierarchically lower than the divine, and nor was the divine considered as something separate above it. On the contrary: nature was sacralized and the natural world was supernatural. Spirits were not the abstract, deified figures that they were to become in later cultures but rather served as "magical potentialities" (Mauss 1971, pp. 122-33)—mana, wakan, orenda, manitu, daimon—that moved from one plane of reality to another. No-one was the sole owner of that "magical potentiality": it was rather something that circulated, that must circulate, between nature and society: it was life as a gift, as a "total social fact" (Mauss 1971, pp. 157, 203) that jointly implied all instances of what was real. Gift-giving was a device that linked all members of a group (men and women, ordinary members and chiefs), that linked humans with objects, the living with the dead, humans with their daimons. This makes up a symbolic whole that links together the various parts of what is real (Mauss [1924] 1971, p. 195). This is a magical world accounted for in mythologies where reality is expressed symbolically ${ }^{1}$.

Roberte Hamayon observes that in the world of farmers and shepherds, unlike that of hunter gatherers, "the supernatural (la surnature) becomes vertical, and with that relationships become hierarchical, humans no longer treat it as an equal. They feel that their commitment to the supernatural is no longer based on a position of equality but on a dependence relationship. Human beings venerate and implore their ancestors, who are located above them in both time and space, because they believe that they reside in the mountains overlooking their pastures, and they hope for their protection" (Hamayon 1990, p. 737). Marcel Hénaff ([2002] 2010, p. 171) argues that what has happened is that the alliance-type relationships characteristic of hunter-gatherers were replaced by relationships based on kinship and lineage, so gifts were no longer bestowed by nature but by ancestors and heirs. Animals and plants were no longer free beings that lived in nature but were produced (as livestock raised, fenced in and branded, owned by someone, and as crops and plants grown by peasants) by human hand.

1 Merlin Donald (1990) established the main outlines of an evolutionary process that began with Homo Erectus and the mimetic culture two million years ago, continued with the mimetic/symbiotic culture described here as from around 250,000 years ago and led to the theoretical culture that peaked in the Axial Age. 
When wild animals belonged to no-one but nature they could not be sacrificed, because they were not property. However, once they were appropriated by human beings they could be sacrificed to give back to the gods (no longer to daimon spirits) what had been received from them. This is where offering was transformed into sacrifice. Marcel Hénnaf holds that in hunter-gatherer societies animals were the incarnation of a daimon-spirit ally, but in farming societies they were split into two: domesticated animals (which were friendly and sacrificeable) and wild animals (which no longer represented deities, were not allies of human beings and were not sacrificeable) (Hénaff [2002] 2010, p. 173).

What reasons can be called on to interpret this transition from an alliance-exchange-giving between living beings through the daimon-mana to sacrifice as mediation between humans and gods? I believe that there are at least two fundamental reasons: the first is the rise of the altar as a place of sacrifice (Harrison 1912, p. 147), which displaces eating together based on the idea of everyone being equal. In sacrifices on an altar three distinct figures emerge: the offeror, the sacrificial victim which is offered up and the god, separate from mortals, to whom the offering is made. This idea is analyzed in greater detail in the next section. The second reason is that religious value ceases to reside in the alliance-exchange-giving and its symbolic expression in the magical potentiality of the Daimon-mana, and instead begins to take the form of a distinction between the transcendent world and the immanent world (Weber 1978, p. 412; Eisenstadt 1986, pp. 1-29; Schwartz 1975, vol. 2, pp. 3-4), as a particular and rather historical variant of the set of systems for the universal, dualistic classification of social reality into the sacred and the profane as postulated by Ėmile Durkheim, and above all of the supramundane and inframundane areas that emerged in the Axial Age, as described by Max Weber and S. N. Eisenstadt.

\section{Conceptual Origins of Sacrifice}

Once the social origins of sacrifice have been established, it becomes possible to pin down its conceptual structure. William Robertson-Smith asserts (and this is one of the crucial aspects of sacrifice as a constitutive ritual) that "the victim was naturally holy, not in virtue of its sacrificial destination but because it was an animal of holy kind" (Robertson-Smith [1889] 1972, p. 390). However, there is a methodological error here: how can the victim be considered as holy per se, before the sacrifice, if, as stated above, in farming societies only the realm of the divine can be holy? It must be recalled that in hunter-gatherer societies the daimon-mana-giving circulated from one milieu to another and was not owned by any single one of them. It is in farming societies, where the transcendent world (bringer of the sacred) has been separated from the immanent/profane world, where the "procedure consists in establishing a means of communication between the sacred and the profane worlds through the medium of a victim, that is, of a thing that in the course of the ceremony is destroyed" (Hubert and Mauss [1898] 1981, p. 97, their italics) ${ }^{2}$. Contrary to what Robertson-Smith believed, Hubert and Mauss held that the victim did not necessarily come with a religious nature already perfected and a clearly defined religious nature: it is the sacrifice itself that confers this upon it (Hubert and Mauss [1898] 1981, p. 97). It is the sacrificial ritual that imparts sacredness to the victim. It is the ritual that creates sacredness: it does not exist per se. The sacredness of the victim does not exist as a prior idea or belief but comes about only through the ritual. The existence of this sacredness precedes the essence of/belief in it. What makes something sacred is the collective feeling that accompanies it. Only through the appropriating event of the ritual does sacredness emerge as something distinct from the profane. Through intensified action and emotional energy, the ritual not only brings about a transcendence of the world taken for granted, the everyday, profane world, to create the "sphere of the sacred" (Durkheim [1912] 1982,

2 Claude Levi-Strauss defines sacrifice in similar terms as "an irreversible operation (the destruction of the victim) in order to release, on another level, an equally irreversible operation (the granting of divine grace), which is required by the fact that two "recipients" situated at different levels, have previously been brought into communication" (Levi-Straus 1964, p. 327). For more about the social origins of the guiding distinction between the sacred and the profane and its historical metamorphoses, see the paper by Beriain (2015, vol. 151, pp. 3-22). 
p. 205) and, by extension, sacralizing the victim, but also unifies individuals and thus gives rise to a single collective whole. Sacrifice is the bridge that links the two worlds and at the same time the door that separates them: a door that can only be opened by ritual, through the practice of sacrifice. It is an act that requires giving and receiving, but with the intermediation of a subject that is immolated. This is an innovation in comparison with mere "offering". Humanity must give back, even if only in small measure, what it has received as a gift from the gods (no longer from nature): the victim is the device for mediation with the world of the sacred (the gods) and also the counter-gift offered up by the human world in payment of the debt of humanity to god ${ }^{3}$. Ultimately, sacrifice leads to an exchange of gifts and counter-gifts similar to that described by Marcel Mauss in his Essay on the Gift in 1924, by E. E. Evans-Pritchard ([1956] 1981, p. 326) and by Marcel Hénaff ([2002] 2010, p. 200). It is a "means of symbolic communication that jointly involves the sacred and profane worlds that make up the real" and thus form a "total social fact" (Mauss [1924] 1971, pp. 157, 203). Not only that, but "[s]acrifice is a religious act which, through the consecration of a victim, modifies the condition of the moral person who accomplishes it" (Hubert and Mauss [1898] 1981, p. 13, their italics).

But what elements are involved in sacrifice? The first point to take into account is that sacrifice is a rite of passage (Arnold van Gennep [1909] 1986, p. 103 et seq.), i.e., it requires that a number of rules for purification be followed, without which it is not possible to pass from the profane world to the sacred world (sacralization) and vice versa (desacralization). According to Hubert and Mauss the first step in the ritual is the "entry into the sacrifice", in which the key roles are those of the "sacrifier [... ], the subject to whom the benefits of sacrifice thus accrue or who undergoes its effects [ ... ]. This subject is sometimes an individual, sometimes a collectivity" (Hubert and Mauss [1898] 1981, pp. 10, 20 et seq.) and the sacrificer, the intermediary, the priest, the visible agent of consecration, who stands on the threshold of the sacred and profane worlds and represents them both at one and the same time. They are linked in him (Hubert and Mauss [1898] 1981, pp. 22-25). The next major element in the sacrificial process, according to Hubert and Mauss, is the victim. The priest, the altar and fire are also essential elements. The sacrifier comes into contact with the victim only through the priest/officiator/sacrifice, and the latter does so not directly but through the instruments provided for that purpose. The sacred and the profane may not "touch each other" directly, but must do so through the mediation of the sacrificial victim. The culmination of the ceremony comes with the death of the victim, once the spirit that inhabited the profane body of the victim enters the sacred world of divinity. The priest/sacrificer charged with taking the action has to undergo an act of purification on exit, like the "expiation of a criminal" who has killed someone. This act of destruction represents the essence of sacrifice, when the victim is separated once and for all from the profane world, sacrificed and therefore "consecrated" (Hubert and Mauss [1898] 1981, p. 35). Hence the etymology mentioned above of sacrificium (sacer, "holy"; facere, "to do"). The victim now becomes a creature reborn, but in the sacred world. The final element in the ritual process is the instance to which sacrifice is addressed, i.e., the divinity, which holds ontological pre-eminence in the system of classification of farming societies in which sacrifice is practised. However, just as the ritual process began with a rite of entry, it ends with rites of exit. The closest, clearest example can be found in the Roman Catholic mass, when after communion the priest cleans the chalice and wipes his hands. Once this has been done the mass is ended, the ceremonial cycle is completed and the priest utters the words of dismissal: Ite, missa est. Similar exit rites can be found in the Brahmanas.

3 However, in the Exchange of gifts studied by Mauss ([1924] 1971, pp. 155-267, 213-15), under the heading of receiving-giving-offering back, individuals must always offer more than they receive (in fact they must offer themselves in the exchange) in the sacrifice in which there is an exchange between humans and gods. Durkheim asserts that in reality a person "gives to sacred beings a little of what he receives from them and he receives from them all that he gives them" (Durkheim [1912] 1982, p. 317). In other words, humans always receive more than they give to the gods. 


\section{Archetypical Anti-Sacrificial Landmarks and the New Anti-Immolation Narrative}

The end of the fascination with immolation, sacrificial ritual and victims led to a major metamorphosis in sacrifice. It lost some of its characteristic traits-those related to the act of immolation-but that does not mean that it died out, since it still maintained its core significance as a relational nexus between the sacred and the profane. Within the profane, secular world sacrifice continued to exist, as shown below. It was the narrative and the heterodox construction of symbols that arose subsequently in Hebrew monotheism that were to bring the question of ethics into the heart of sacrificial practice. There was a shift in the axis of the relevance of the divine to the human world, and especially in the idea of the sacrifice of human beings, through the mediation of virtuous men of religion (prophets) who came out of the ethical prophecies of the great Semitic tradition. The main point of this major shift in emphasis lies not so much in the point of origin of a myth in the past as in the persistence of the subsequent narrative in communities of interpretation and action. Without the unique promises of the great unknown writer of the time of exile who drew up the prophetic theodicy of suffering, misfortune, poverty, humiliation and ugliness, especially the doctrine of the Servant of Yahweh which teaches that although blameless he suffered and died voluntarily as an expiatory victim, the subsequent development of the Christian doctrine of the martyrdom of the divine Savior would not have been possible (Weber 1987, 21 and ss).

Without doubt, one of the landmarks of this narrative is the story of Abraham and the non-consummated sacrifice of his son Isaac. God tempted Abraham, saying to him "Take now thy son, thine only son Isaac, whom thou lovest, and get thee into the land of Moriah; and offer him there for a burnt offering upon one of the mountains which I will tell thee of" and just when Abraham was about to sacrifice his beloved son, God spoke to him again: "Lay not thine hand upon the lad, neither do thou any thing unto him: for now I know that thou fearest God, seeing thou hast not withheld thy son, thine only son from me". Sören Kierkegaard wrote in Fear and Trembling that to be absolutely responsible to God, Abraham must sacrifice his ethical duty, precisely because he loves his son unconditionally, on the altar of his unbreakable faith in God, which makes him religiously a devout believer but ethically a murderer (Kierkegaard 1976, pp. 105-6; Derrida 1995, p. 65; Gordon 1995, p. 60; Zulaika and Douglass 1996, p. 123 et seq.; Zulaika 2020). God himself, in an anti-sacrificial attitude, stays Abraham's hand from killing. The latter's exercise of faith, on the same level as his love for his son, sublimates the action of sacrifice or at least leaves it in suspension. In principle faith, trust in God, acts as a functional equivalent of sacrifice.

The Abrahamic and Kierkegaardian ambivalence of being a believer or a killer is diffused in Jesus Christ, perhaps the strongest link in the anti-immolation narrative. René Girard ([1978] 1982, p. 214) states that the heart of this shift away from sacrifice lies in the Gospel of St Matthew. In his incarnation as a human being Christ, the bearer of the divine, takes on the suffering, the pain of being cast into the world (recall the words of anguished impotence and final abandonment of Jesus on the cross, when he cried "My God, my God, why hast Thou forsaken me? (Eli, Eli, lama Sabachtani)". Girard proposes a re-mythologization, a shift in the narrative or sacrificial ritual, presented as a symbolic realization in which the myth of bread and wine (metaphor) symbolizes a new gift-giving which is materialized with the presentialization of the sacred (sacrament) through a humanized God (both victim and God). This sacrificing of God heralds the end of sacrificing to God. This is where the sacrifice of sacrifice itself can be said to begin (Keenan 2005, pp. 124-25). The truth of the sacrifice that is revealed in the crucifixtion, in the kenosis of Christ, destroys once and for all the reason for all sacrifices. This mystery is the self-humiliation, kenosis, of God, who descends from the infinite majesty of divinity to take the form not just of a human being as such but of a human being who is rejected, mocked and ultimately killed in the most degrading circumstances. By taking on the evils of the world, Christ announces a reconciliation with no ulterior motives and no sacrificial intermediaries. The ethics of Jesus' Sermon on the Mount are linked to an alliance (the third, the first being with Abraham and the second with Moses) which will excise violence from the community. In Christianity the new prevailing tone is that of love: "[f]or God so loved the world that he gave his only begotten Son, that whosoever believeth 
in Him should not perish but have everlasting life". However, this God loves not only the chosen people but the whole world. Salvation depends on faith and is conceived as a gift from God, while in the old testament scriptures the giving went in the opposite direction, i.e., sacrifices to God and obedience of his commandments (Parsons 1978, p. 271); the only condition is faith, trust in God. Not even works are ultimately a determinant. Taking Marcel Mauss's 1924 Essay on the Gift as a reference point for his interpretation, Talcott Parsons (1978, pp. 264-99) analyses death as a major contributor to the evolutionary enhancement of life, and thereby it becomes a significant part of the aggregate "gift of life" that all particular lives should end in death. He makes no reference to sacrificial elements, but asserts that "Death acquires a transbiological meaning because the paramount component of its meaning is the giving of life, at the end of a particular life, to God (or to man) as an expression of love for God (or man). This seems to symbolize the conception of a perpetual solidarity between the bio-human level, symbolized by the blood of Mary, and the divine level, symbolized by the blood of Christ. In the ideal Christian death, one came to participate in the blood of Christ at a new level. This is the reciprocation of God's gift to mankind through Mary" (Parsons 1978, p. 275).

In the plot of Sophocles' Greek tragedy Antigone, King Creon refuses to allow the body of Polynices to be buried following the rites established for heroes who have fallen in battle. His sister Antigone attempts to have him buried with honours and Creon sentences her to be buried alive. She then decides to hang herself. This tragedy has been interpreted in many different ways (Lacan 1992; Butler 2002; Irigaray 1992; Heidegger 1984, pp. 145-46), but a common thread running through those interpretations is the fact that the institutive power of sacrifice represented by Antigone competes with and questions the instituted power of sacrifice which Creon seeks symbolically to monopolize. This act of ethical appropriation on the part of Antigone entails to some degree an act of political expropriation of Creon, of his symbolic male dominant order and of the gods that he represents. Antigone appears as a woman who acts autonomously, as a pure and simple link between the human being and that of which he miraculously happens to be the bearer, the signifying cut that confers him the indomitable power of being what he is in the face of everything that may oppose him, both the gods above and those below, including death, as the possibility of absolute impossibility (Lacan 1992, p. 282).

Christianity rejects the idea of violent (ritual) sacrificial death and revolts against it, even when it wears the trappings of martyrdom. After St Paul, the idea of the sacrifice of the Son of God became intolerable unless it could be understood as a mechanism for assuring his resurrection and return to life as a spirit/daimon that lives among us. Sacrifices, especially blood sacrifices, were at the heart of religious activities in the farming societies of the ancient world, especially official, public religious activities, but with the law introduced by Constantinius II in the 4th century things shifted to "sacrificiorum aboleatur insania" (Stroumsa 2009, pp. 57-58). Guy Stroumsa states that among the Jews and other communities sacrifice was replaced by prayer (Stroumsa 2009, p. 63). The destruction of the temple at Jerusalem resulted in a major shift towards rituals without priests or blood sacrifices, where rabbis had no liturgical role. It was no longer the smell of smoke or of roasted meat typical of sacrifice that was pleasing to God. The water of ablutions and baptism has replaced the fire of sacrifice for Christians and Jews, and the soul as an interior temple has transformed rituals of purification into rituals which are ascetic rather than expiatory.

Marcel Hénaff has explored a great many post-immolation realities, focusing on the phenomenon of the "grace of God" (Hénaff [2002] 2010, chp. 7): Kharis in ancient Greek, kharis also in the Christianity of St Paul, gratia in Seneca and St. Augustine and hén in the biblical scriptures. The narrative that focuses on the ambit of grace is a new feature in regard to the ceremonial exchange of gifts and sacrificial rituals per se, given that it entails a rethinking of the social bond, with the emergence of a divine instance that unconditionally grants its grace (divine favor or friendly action) to a whole community of believers. It consists of providing a service for nothing in return. This free service, however, gives rise to acknowledgement. Generosity and acknowledgement (Benveniste 1969, vol. 1, pp. 199, 201) therefore appear as jointly involved. Grace is always something extra, over and above "what counts", what is oligatory or predictable; "it belongs to the register of the extraordinary (hence 
its association with the sacred)" (Pitt-Rivers 1993, p. 284). Kharis can be seen as designating the state of a subject (such as joy or pleasure), an attribute of an object (such as charm or beauty, hence the Three Graces by Raphael and Rubens) or the resulting attitude (gratitude) (Hénaff [2002] 2010, p. 245). There are several verb phrases that convey the diverse meanings of grace: gratias agere (to give thanks), gratiam debere (the duty of acknowledgement), gratiam referre (to do a favour) and gratiam inire (to earn someone's good graces).

The Hebrew equivalent of the Greek kharis is hen, which refers to the gift-the gesture of generosity-of the one God. It means a benevolent act by a person of high rank towards one of lower rank. The initial gift of Yahweh is precisely the choosing—bahhar-of his people from among many other peoples, as an opening, sovereign gesture confirmed through numerous divine initiatives such as the calling of Abraham, the gift of land, the exodus and the first kingdom. That gift received as a people can never be reciprocated or equaled, and it is important to recognize that impossibility, based on the strictly unconditional, transcendent, inexplicable favour of Yahweh. The chosen are linked via the bond — berith — that refers them to a higher, giving instance in the form of Yahweh (Hénaff [2002] 2010, pp. 253-54), so the bond is one of vassalage, protection and dependence/ subordination, in contrast with the bond of interdependence and alliance between hunter-gatherers and their daimons.

\section{The Clash of the Sacrificial and Anti-Sacrificial Narratives in Modern Times}

Societies do not always sacralize the same realities. In the first place, as seen above, societies made up of groups of hunter-gatherers sacralize nature (la surnature). Secondly, gods in the West/impersonal powers in the East were sacralized in the Axial Age, and their bearers were groups of farmers. A third landmark is the sacralization of a king or governor as "the highest of men and the lowest of gods, the link between the dead, the living and the immortal" (Joas 2017, p. 463). In ancient societies the fusion of sacrality and highly concentrated power gave rise to new social constellations (Erkens 2013, pp. 15-32; Joas 2017, p. 465). Royalty stems from charismatic heroism (Weber 1978, p. 875). Fourthly, in the 18th century there was a collective self-sacralization that entailed changes in the idea of the sacred governor in the Age of Absolutism ("he who sits on the divine throne and is appointed by Him". Louis XIV: Le Roi-Soleil). This in turn gave rise to a potential opponent of the king represented by another subject of sacralization: the people of the nation. With the "people of the nation" an "in group/outgroup" distinction emerged in a narrative created mainly by the different varieties of nationalism, which led to a form of sacralization of the "people of the nation" or "the nation" resting on "true, sacred customs" which have somehow been profaned (Akenson 1992).

\subsection{The Narrative of the Sacralization of the Nation and the National Hero}

The clash between the sacrificial/apocalyptic (Smith 2005) and anti-sacrificial narratives continued into the Age of Modernity. The nation, as the new "god-totem", continued the narrative of sacrifice and took over the place once held by classical divinity, creating its own altars, monuments and sacrificial, ritual commemorations.

But in the centuries that elapsed from early Christianity to the 18th century major semantic transformations took place in the narrative of sacrifice. It would not be possible to understand the culture of sacrifice in the early part of the Age of Modernity without considering those transformations.

\subsubsection{The Transition to Modernity: "Pro Patria Mori"}

In the blend of conceptual horizons that came with Aristotle, Christian patristics and Renaissance and Baroque humanism, there was a major secularization of categories, since the old metaphor of the marriage between bishops and their seats served to interpret relations between princes and the state: "And just as men are joined together spiritually in the spiritual body, the head of which is Christ ..., so are men joined together morally and politically in the res publica, which is a body the head of which is the Prince" (Kantorowicz 2012, p. 229). In the Middle Ages, "the duty to defend the patria was higher than the feudal obligations of vassal to lord" (Kantorowicz 2012, p. 246). This new patriotism was 
nourished by values transferred from the patria of Heaven to the political communities of the earth. In the Crusades both knights and common soldiers could gain immediate entry into the Kingdom of Heaven, and in return for their sacrifice could obtain the crown of martyrdom in the other life. This is paradoxical, given that Christ sacrificed himself to prevent further sacrifices, but in seeking to put an end to the sacrificing of propitiatory victims, that sacrifice had the unintended consequence of becoming a form of sacrifice in which the core figure was the martyr, a pattern that was to continue into the idea of the national hero in modern times (Beriain 2011).

Fighting and dying for one's homeland came to be seen as a victory and remedy for the soul. Those who died in a campaign for their brothers (sacrificio pro fratribus), in a "holy war", emulated Christ's sacrifice for his brothers and sisters and offered themselves to God. Marcus Tullius Cicero put it this way:

Who that is true would hesitate to give his life for her [one's native land] if by his death he could render her a service? (Cicero 2018, p. 49)

Those who fall on the field of battle for the res publica are glorified. What was good for Rome, the once capital of the world, served equally well for the incipient national monarchies in the kingdoms of Great Britain, France, Spain, etc. Loyalty to these new, territorial patrias, which included the subjects of the Crown, replaced the supranational bonds that had been used by the now fragmented Roman Empire. In this context, death for one's country as a "martyr" took the church as its reference point and adapted ecclesiastical formulae to the secular body politic. As pointed out by Kantorowicz, "... death on the battlefield for the political corpus mysticum headed by a king who was a saint and therefore a champion of justice, became officially "martyrdom" (Kantorowicz 2012, p. 266). In this way, the corpus mysticum patriae was contrasted with the corpus mysticum ecclesiae. Patria was presented as an immortal, timeless entity invested with a unity that does not die, in the perpetuity of the people of the nation.

The tone of glory in self-sacrifice and the idea of transcending death have never been better expressed than in Pericles' funeral prayer for the Athenians who fell in the first year of the Peloponnesian War, composed by Thucydides:

"They gave their lives, to her and to all of us, and for their own selves they won praises that never grow old, the most splendid sepulchres -nor the sepulchres in which their bodies are laid, but where their glory remains eternal in men's minds, always there in the right occasion to stir to speech or action. For famous men have the whole earth as their memorial: it is not only their inscriptions on their graves in their own country that mark them out; no, in foreign lands also, not in any visible form but in people's hearts, their memory abides and grows. It is for you to try to be like them. Make up your minds that happiness depends on being free, and freedom depends on being courageous. Let there be no relaxation in face of the perils of war". (Book II, Thucydides 1959, p. 121)

5.1.2. The nation as a New "Sacred Form" of Modernity with Its Altars, Monuments and Sacrificial Commemorations

The referents of the idea of "nation" are political power and "things national". It is a specific type of pathos which is linked to groups of humans united in a "community of people who share a common language, or religion, or common customs or political memories; such a state may already exist or it may be desired. The more power is emphasized, the closer appears to be the link" (Weber 1978, p. 327). However, among all the intangibles of the glue binding the community that this pathos establishes there is something missing; and that something is the sacrifice of a national hero who gives his/her life for the nation (Marvin and Ingle 1999, vol. 2, p. 63). Taking the later works of Durkheim and Girard as 
a reference point, Caroline Marvin points to the flag as a modern totem. The members of the totem group face, sooner or later, the limits of what is familiar and known and they reach the border, an area of confusion where identities are exchanged between insiders (nationals) and outsiders (immolated national heroes), and cross over. The crossing is violent and bloody, sacrificial in a word. This dramatic encounter with death marks the exact border of the community. The act of crossing establishes a clear contrast between who is inside and who is outside the community. Border crossers become outsiders, dead (immolated national heroes) to the community. The flag marks the point of their crossing. It is the symbol of those who have crossed, of devotees transformed. The community celebrates and reveres its insiders turned outsiders, taking steps lest they come back and punish those who did not cross over. From within the boundaries, the community fears and worships these outsiders (fallen heroes) it consumes to preserve its life (Marvin and Ingle 1999, p. 67). The community welcomes these returning border-crossers who have sacrificed themselves on the altar of the nation back to the fertile center by removing the mark of death they carry in piacular rituals in which there is a collective communion. Thus, "a hero's death for the freedom and honor of our people is a supreme achievement that will affect our children and children's children. There is no greater glory, no worthier end than to die this way. Additionally, to many, death gives a perfection that life would have denied them" (Weber 1995, p. 724).

In the narrative of the nation as told by nationalism there is a Golden Age, a driving myth which is projected as utopia into the future, as opposed to the historical contingencies of the present, but which is only attainable through commitment and self-sacrifice on the part of its members. This is what the nation continually defends, remembers and celebrates (Smith 2003, p. 218). The sentiments and symbolism expressed by Pericles served as models for shaping the political solidarity and civic nationalism of the Enlightenment and, by extension, of the French Revolution. The symbols inscribed and hinted at on monuments, the land and its occupants as an intangible sepulchre and the emulation of the courage of those who sacrificed themselves shaped a "secular religion" of the general will (Mosse 1975, vol. 2, pp. 71-72; 1990, pp. 33, 36, 38) in which the people of the nation venerate themselves. As stated by Bauman: "The hero's death was transcended, just as the death of the martyr had been-this time not by the salvation of the immortal soul of the dying but by the material immortality of the nation" (Bauman 2005, p. 44).

The modern reappropriation of sacrifice was to result in a new twist in the semantics of death. The existential nature of humanity described by Heidegger as "being for death" shifted towards "being for killing". But while dying is a solitary act, killing takes two. Mortui viventes obligant, so to justify this society introduces a new political performativity through a number of appropriating events that make up a national mystique, a community of worship in which great importance is given to the fallen within a politics of the masses, with new identifying totems and monuments-pyramids, obelisks, towers, statues, sarcophagi (Koselleck 2020, p. 66; Casquete 2020, p. 295 et seq.) that represent the eternity of time and in which the killed and the fallen are welcomed: heroes, victims, martyrs, conquerors, militants and, perhaps, the vanquished. This new culture of commemoration seeks to elevate human beings above their day-to-day routines by provoking feelings of fear, as if they were in a sacred temple linked to a community of worship. In pre-revolutionary times death was represented not as an ending but as a transition to another world, but it was presented as differentiated in terms of estates, i.e., kings, princes and warrior heroes were the bearers of that perpetuity that "never dies". However, with the onset of the Age of Modernity, from the French Revolution onwards, two major changes took place (Koselleck 2020, pp. 71-72): on the one hand the ideas of the intramundane representation of death came to carry more weight, i.e., a decline in the Christian interpretation of death left a gap for meanings based on purely political and social reasons. Post-Christian writings and linguistic forms refer to the earthly future of each state or people. On the other hand, earthly immortality, hitherto reserved for the great, became generalized in the name of all. This intramundane viewpoint was followed by a dismantling of the system of estates, i.e., a democratization of death. The attributes enshrined in St George as a helper, a savior and a monarch were superseded after World War I by the Tomb of the Unknown Soldier (Mosse 1990, pp. 36-38), who answers for the nation of which he forms part. There is 
an inward equality of the fallen for the homeland-a national homogenization in the face of death-but no outward equality. In a comment filled with acid irony the lead character in Charlie Chaplin's film Monsieur Verdoux (played by Chaplin himself), which was not too far removed from the arguments set out here, asserts that individual killers spark widespread rejection in the collective consciousness but mass killing sanctifies and creates heroes. In mass deaths there is a transfiguration of the meaning of death itself.

\subsection{Landmarks in the Anti-Sactificial Narrative of the Sacralization of the Person}

After the French Revolution, and above all after the two world wars and the horror of the Shoah, the legacy of the anti-sacrificial narrative was recovered in civil life, in dynamic tension with the sacrificial narrative of the nation. This post-sacrificial narrative postulates that it is a crime to kill the victim (a human person) because it is sacred, so there has been a change from the sacrificial sacralization of the victim to the anti-sacrificial sacralization of the human person. This is something that appears quite clearly in a publication by Emile Durkheim in 1898, brought up by Hans Joas (2017) ${ }^{4}$, and has been confirmed institutionally in the various declarations of human rights $(1776,1789$ and 1948). During the unrest that arose from the scandal of the Dreyfus Affair in 1898, Durkheim wrote:

"This human person (personne humaine), the definition of which is like the touchstone which distinguishes good from evil, is considered sacred in the ritual sense of the word. It partakes of the transcendent majesty that churches of all time lend to their gods; it is conceived of as being invested with that mysterious property which creates a void about sacred things, which removes them from vulgar contacts and withdraws them from common circulation. And the respect which is given it comes precisely from this source. Whoever makes an attempt on a man's life, on a man's liberty, on a man's honor, inspires in us a feeling of horror analogous in every way to that which the believer experiences when he sees his idol profaned. Such an ethic is therefore not simply a hygienic discipline or a prudent economy of existence; it is a religion in which man is at once the worshipper and the god". (Durkheim [1898] 1973, p. 46)

This idea is not foreign to Christianity. Durkheim himself states this in his 1898 publication: "Christianity demonstrated in its inner faith, in the personal conviction of the individual, the essential condition of divinity ... The very center of moral life was thus transported from the external to the internal, and the individual was thus elevated to be sovereign judge of his own conduct, accountable only to himself and to his god" (Durkheim [1898] 1973, p. 52). It is an error to present this sacralization of the human person and its associated moral anchoring as antagonistic to Christian morality. Indeed, it derives precisely from that morality. By taking this on board we are not denying our past but continuing it.

Several of Jeffrey Alexander's more recent works (Alexander et al. 2004, 2013; Alexander 2013) contrast the two narratives mentioned here. On the one hand the tragic/apocalyptic narrative is based on aggressive heroism that vanquishes and kills enemy forces, so success is measured as the highest possible number of enemy casualties. This results in civilian and military victims who are irremediably traumatized by events that have caused them suffering, and thus turns trauma into an essential characteristic of their lives and circumstances. On the other hand, under the defensive/progressive narrative, soldiers risk and sometimes give their lives helping to retrieve wounded comrades. The significance of one's own suffering and that of others push them into performing acts of salvation, healing and care of victims and acts to improve the world. Mass deaths in war have been seen and morally justified as sacrifices pro patria under the tragic/ apocalyptic narrative. However, this changes "when narratives of triumph are challenged, when individual deaths seem

4 Viviana Zelizer has studied the social processes that have led to the sacralisation of the child (Zelizer 1985). By the same author (Zelizer 2015), Part One: Valuation of Human Lives, pp. 35-123. 
worthless or polluted, when those who have fallen are seen not as sacrificing for a noble cause but as wasted victims of irresponsible chicanery, that wars can become traumatic indeed" (Alexander 2013, p. 3), as occurred in the Vietnam war, which did not end in victory for the US. With this interpretational framework, recent research by Richard Lachmann (2016, pp. 323-58) shows a transformation in the culture of sacrifice through an analysis of the significance of the Medals of Honor awarded by the US Government to the families of those fallen in combat between 1861 and 2014. In the "pyramid of honor" that pays homage to awardees up to 1918 priority was given to the valor and intrepidness of soldiers in risking their lives beyond the call of duty. From 1963 onwards the post-Vietnam narrative changed the significance of the medal, emphasizing "noncombatant bravery", manifested through feats that resulted in the saving of military and civilian lives in fire-fights and bombings. The priority became avoiding victims, saving lives, rather than manufacturing victims. This was a major narrative shift in the cult of the nation and its commemorations. It also represents a way of paying military honours to soldiers in both victory and defeat, and ultimately undermines the ethos of self-sacrifice in the narrative of tragedy. However, in today's info-wars ("from soldier to drone driver"), combatants face each other in asymmetric conflicts in which one side is the hunter, armed with sophisticated weapons and technical systems, and the other is the hunted, equipped with inferior technology that leads it to assume a heroic role in the face of unseen death (Zulaika 2020).

Ullrich Bröckling (2020) detects two opposing tendencies in today's societies: on the one hand, from the 1980s onwards the attribute of being "post-heroic" has become increasingly plausible in various contexts, and on the other hand not a day goes by without new heroes and heroines appearing or old heroes being revived as emblematic figures or idealized human beings. Considering that we live in and project horizons of normative expectations and orders which are no longer hierarchical but heterarchical and therefore different from tradition, and more flexible frameworks of classification as conformity or deviation towards what is considered normal (Zerubavel 2018), the position of the individual in a highly complex, technified society, the models of leadership and, of course, the problem of the spirit of self-sacrifice and abnegation (and with it the attitude towards death) have changed drastically, so it is unlike the position of the heroes of the sagas, the redeeming heroes and the holy heroes described by Wilhelm Wundt ([1912] 1990, p. 335 et seq.). Western societies are no longer in a position to mobilize large numbers of people to give their lives "heroically" in the name of the nation's "tribal gods" (Isaacs 1975; Marvin and Ingle 1999). Modern-day heroes and heroines are characterized much more by their nonconformist positions critical of obedience. The impulse towards heroism manifests itself as civil courage, e.g., in Tiananmen Square in 1989, among fire-fighters and police officers on 9/11, in the activists currently fighting against climate change, against male dominance and in the Black Lives Matter movement and in the essential workers who have saved thousands of lives in the coronavirus crisis. At the same time heroism has become democratized and become an everyday phenomenon ("just for one day" as the David Bowie lyric puts it and as in Andy Warhol's statement that nowadays everyone can have their "fifteen minutes of fame"). This is related to changes in the ambit of creativity in modern societies, as creativity in post-modern times (unlike the tradition in which creativity was reserved for an elite) brings together two important, widespread issues: the subjective desire for creativity, i.e., the desire to be creative, and the objective imperative to be creative, i.e., the idea that one must be creative (Reckwitz 2012, p. 13).

\section{Conclusions}

The emergence of heroic and post-heroic figures begs the question of who needs such figures and why (Habermas 2003, p. 43). The answer may lie in different perceptions of crises and different desires for normalization; because wherever heroes appear they are a sign of underlying problems (Bröckling 2020). Heroes are symptoms of a social crisis, but that does not mean that they are the solution to it. Indeed, it is in the clash between heroic and post-heroic image guidelines that some of the lines of conflict of contemporary societies lie. 
The genealogy of the various forms of sacrifice shows that as a communication link between the profane and the sacred which appeared with the emergence of farming societies, distinct from the idea of offering and with the immolation of a victim at its core, it has resulted in the creation of a powerful tragic/apocalyptic narrative whose influence can still be felt today in both religious and secular terms, within which the nation has created its own worship community.

Within the heterodox tendencies arising out of Hebrew monotheism that postulate the figure of a divine savior, there was strong criticism of immolation as a device and an affirmation of the ethical aspect of defending sacrificial victims. The influence of this criticism also spread over time in secular terms, giving rise to a no less important progressive/pacifist narrative. However, the dynamic tension between these two narratives leads to major lines of conflict in present-day societies.

Funding: This translation was funded by I-Communitas. Institute for Advanced Social Research (Public University of Navarra). This research was funded by the National Project "Variedades de la experiencia creativa y modelos de sociedad" (REF: CSO2017-85052-R) granted by Ministerio de Economía y Competitividad (Spain).

Conflicts of Interest: The author declares no conflict of interest.

\section{References}

\section{Primary Sources and Collections}

Biblia de Jerusalén. 1998. Bilbao: Desclée de Brouwer.

\section{Secondary Sources}

Akenson, Donald Harman. 1992. God's Peoples. Covenant and Land in South Africa, Israel and Ulster. Ithaca: Cornell University Press.

Alexander, Jeffrey C. 2013. Trauma. A Social Theory. Cambridge: Polity Press.

Alexander, Jeffrey C., Ron Eyerman, and Elizabeth Butler Breese, eds. 2013. Narrating Trauma. On the Impact of Collective Suffering. London: Palgrave.

Alexander, Jeffrey C., Ron Eyerman, Bernhard Giesen, Neil J. Smelser, and Piotr Sztomka. 2004. Cultural Trauma and Collective Identity. Berkeley: University of California Press.

Bauman, Zygmunt. 2005. Liquid Life. Londres: Polity Press.

Benveniste, Emile. 1969. Le vocabulaire des institutions indo-européennes II. París: Les Editions de Minuit.

Beriain, Josetxo. 2011. El sujeto transgresor (y transgredido). Barcelona: Anthropos-Siglo XXI.

Beriain, Josetxo. 2015. “Genealogía afirmativa” del hecho religioso en perspectiva sociológica. Revista Española de Investigaciones Sociológicas, REIS 151: 3-22.

Beriain, Josetxo. 2017. Las metamorfosis del don: Ofrenda, sacrificio, gracia, substituto técnico de Dios y vida regalada. Revista Politica y Sociedad 54: 641-63.

Bröckling, Ullrich. 2020. Postheroische Helden. Ein Zeitbild. Francfort: Suhrkamp.

Butler, Judith. 2002. Antigona's Claim. Kinship Between Life and Death. New York: Columbia University Press.

Casquete, Jesús. 2020. El culto a los mártires nazis. Alemania, 1920-1939. Madrid: Alianza.

Cicero, Marcus Tullius. 2018. Los deberes. Madrid: Gredos.

Derrida, Jacques. 1995. The Gift of Death. Chicago: Chicago University Press.

Donald, Merlin. 1990. The Origins of the Modern Mind. Three Stages in the Evolution of Culture and Cognition. Cambridge: Harvard University Press.

Durkheim, Emile. 1973. Individualism and the Intellectuals. In Emile Durkheim on Morality and Society. Edited by Robert Neelly Bellah. Chicago: University of Chicago Press, pp. 43-57. First published 1898.

Durkheim, Emile. 1982. Las Formas Elementales de la Vida Religiosa. Madrid: Akal. First published 1912.

Eisenstadt, Shmuel Noah. 1986. "Introduction" in The Origin and Diversity of Axial Civilizations. Edited by Shmuel Noah Eisenstadt. Albany: State University of New York Press, pp. 1-29.

Erkens, Franz-Reiner. 2013. Herrschersakralität. In Sakralität und Sakralisierung. Perspektiven des Heiligen. Stuttgart: Editorial Franz Steiner.

Evans-Pritchard, Edward Evan. 1981. La religión Nuer. Madrid: Taurus. First published 1956.

Girard, René. 1982. El misterio de nuestro mundo. Salamanca: Sígueme (Abbreviated NMN). First published 1978. 
Gordon, Neil. 1995. Sacrifice of Isaac. Nueva York: Bantam Books.

Habermas, Jürgen. 2003. Fundamentalism and Terror. A Dialogue with Jürgen Habermas. In Philosophy in a Time of Terror. Dialogues with Jürgen Habermas and Jacques Derrida. Edited by Giovanna Borradori. Chicago: The University of Chicago Press, pp. 25-43.

Hamayon, Roberte. 1990. La chasse à l'âme. Esquissed'une Theorie Chamanienne Siberienne. Nanterre: Societéd'Ethnologie.

Harrison, Jane Ellen. 1912. Themis. The Social Origins of the Greek Religion. Cambridge: Cambridge University Press.

Heidegger, Martin. 1984. Gesamtausgabe. Francfort: Vittorio Klosterman, vol. 53.

Hénaff, Marcel. 2010. The Price of Truth. Gift, Money and Philosophy. Stanford: Stanford University Press. First published 2002.

Henninger, Joseph. 1995. Sacrifice. In The Encyclopaedia of Religion. Edited by Mircea Eliade. London: Macmillan, vol. 11 , pp. 544-57.

Hubert, Henry, and Marcel Mauss. 1981. Sacrifice. Its Nature and Functions. Chicago: Chicago University Press. First published 1898.

Irigaray, Luce. 1992. Belief Itself. In Sexes and Genealogies. Nueva York: Columbia University Press, pp. 23-53.

Isaacs, Harold R. 1975. Idols of the Tribe. Group Identity and Political Change. Cambridge: Harvard.

Joas, Hans. 2013. The Sacredness of the Person. A New Genealogy of the Human Rights. Washington, DC: Georgetown University Press.

Joas, Hans. 2017. Die Macht des Heiligen. Francfort: Suhrkamp.

Kantorowicz, Ernst H. 2012. Los dos Cuerpos del rey. Un estudio de Teología Política Medieval. Madrid: Akal.

Keenan, Dennis King. 2005. The Question of Sacrifice. Bloomington: Indiana University Press.

Kierkegaard, Sören. 1976. Diario de un Seductor/Temor y Temblor. Madrid: Guadarrama.

Koselleck, Reinhart. 2020. Modernidad, Culto a la Muerte y Memoria Nacional. Madrid: Centro de Estudios Políticos y Constitucionales.

Lacan, Jacques. 1992. The Seminar of Jacques Lacan, Book VII. The Ethics of Psychoanalysis, 1959-1960. Nueva York: Norton.

Lachmann, Richard. 2016. The culture of sacrifice in conscript and volunteer militaries: The U.S. Medal of Honor from the Civil War to Iraq, 1861-2014. American Journal of Cultural Sociology 4: 323-58. [CrossRef]

Leakey, Richard E. 1982. Origins. What New Discoveries Reveal About the Emergence of Our Species and Its Possible Future. New York: Dutton.

Leakey, Richard E. 1994. The Origins of Humankind. New York: Basic Books.

Levi-Straus, Claude. 1964. El Pensamiento Salvaje. México: Fondo de Cultura Económica.

Marvin, Caroline, and David W. Ingle. 1999. Blood Sacrifice and Nation. Totem Rituals and the American Flags. Cambridge: Cambridge University press.

Mauss, Marcel. 1971. Ensayo sobre los dones: Motivo y forma del cambio en las sociedades primitivas. In Sociología y Antropología. Madrid: Tecnos, pp. 155-267. First published 1924.

Mauss, Marcel. 1971. Mana. In Sociología y Antropología. Madrid: Tecnos, pp. 122-33.

Mosse, George Lachmann. 1975. The Nationalization of the Masses. New York: Howard Fertig.

Mosse, George Lachmann. 1990. Fallen Soldiers. Oxford: Oxford University Press.

Parsons, Talcott. 1978. The 'Gift of Life' and its Reciprocation. In Action Theory and the Human Condition. Nueva York: Free Press, pp. 264-99.

Pitt-Rivers, Julian. 1993. El lugar de la gracia en la antropología. In Honor y Gracia. Edited by Julian Pitt-Rivers and J. G. Peristiany. Madrid: Alianza, pp. 280-321.

Reckwitz, Andreas. 2012. Die Erfindung der Kreativität. ZumProzessgesellschaftlicherÄsthetisierung. Frankfurt: Suhrkamp.

Robertson-Smith, William. 1972. The Religion of the Semites. The Fundamental Institutions. Nueva York: Schocken. First published 1889.

Robertson-Smith, William. 1886. Sacrifice. In Encyclopaedia Britannica. Chicago: Encyclopædia Britannica, Inc., vol. 21, pp. 132-40.

Schwartz, Benjamin. 1975. The Age of Transcendence. In Wisdom, Revelation and Doubt: Perspectives on the First Millennium B.C. Cambridge: American Academy of Arts and Sciences, vol. 2, pp. 3-4.

Smith, Anthony D. 2003. Chosen Peoples. Sacred Sources of National Identity. Oxford: Oxford University Press. 
Smith, Phillipe. 2005. Why War? The Cultural Logic of Iraq, The Gulf War and Suez. Chicago: Chicago University Press. Stroumsa, Guy. 2009. The End of Sacrifice. Chicago: Chicago University Press.

Thucydides. 1959. The History of the Peloponnesian War. Hardmonsworth: Penguin. van Baal, Jan. 1976. Offering, Sacrifice and Gift. Numen 23: 161-78. [CrossRef] van Gennep, Arnold. 1986. Los Ritos de paso. Madrid: Taurus. First published 1909. Weber, Marianne. 1995. Max Weber. Una biografía. Valencia: Alphons el Magnánim. Weber, Max. 1978. Economía y Sociedad. México City: FCE.

Weber, Max. 1987. Ensayos sobre Sociología de la Religion. Madrid: Taurus, vol. 3.

Wundt, Wilhelm. 1990. Elementos de Psicología de los Pueblos. Barcelona: Alta Fulla. First published 1912.

Zelizer, Viviana. 1985. Pricing the Priceless Child. The Changing Social Values of Children. Nueva York: Basic Books. Zelizer, Viviana. 2015. Vidas Económicas. Cómo la Cultura da Forma a la Economía. Madrid: CIS.

Zerubavel, Eviatar. 2018. Taken for Granted. The Remarkable Power of the Unremarkable. Princeton: Princeton University Press.

Zulaika, Joseba, and William Douglass. 1996. Terror and Tabu. The Folies, Fables and Faces of Terrorism. Londres: Routledge and Keegan Paul.

Zulaika, Joseba. 2020. Hell Fire from Paradise Ranch. On the Front Lines of Drone Warfare. Oakland: University of California Press.

Publisher's Note: MDPI stays neutral with regard to jurisdictional claims in published maps and institutional affiliations.

(C) 2020 by the author. Licensee MDPI, Basel, Switzerland. This article is an open access article distributed under the terms and conditions of the Creative Commons Attribution (CC BY) license (http://creativecommons.org/licenses/by/4.0/). 